\title{
King of Kings - The Thriumph and Tragedy of Emperor Haile Selassie I of Ethiopia'
}

\section{François Stepman}

Platform for African European Partnership in Agricultural Research for Development

Haile Selassie is one of the most bizarre and misunderstood figures of 2oth-century history, alternately worshipped and mocked, idolised and marginalised. This magnificent biography by the German-Ethiopian historian Asfa-Wossen Asserate, is diligently researched and fair-minded with Selassie being accordedthe level of dignity he deserves. The book is manifestly a riposte to Ryszard Kapuscinski's The Emperor: Downfall of an Autocrat, which portrayed the emperor, and indeed Addis Ababa's entire Amharic elite, as a comic-opera laughing stock.

Selassie came to power as regent of Abyssinia, later Ethiopia, in I9I6, but many of the myths around him originated with Mussolini's invasion of the country in I935. Selassie and his armies resisted, but he was eventually forced into exile. In I94I, after six years of brutal occupation, the Italians were defeated by British and South African forces and Selassie was allowed to return to his throne in Addis Ababa, where he remained in power until i974.

One unexpected side-effect of the plunder of Selassie's sub-Saharan state by a fascist power was to give Jamaica's fledgling Rastafari movement impetus and a cause. The invasion became a dominant event in the Rastafarian narrative of black martyrdom. Selassie was seen as a manifestation of the one true God and a bulwark against "Babylon" (oppressive colonial society). The movement took its name from Selassie's pre-coronation title, Ras Tafari Makonnen.

The Rastafarian movement was not the only radical current in Jamaica to co-opt Selassie. Marcus Garvey, the Jamaican apostle of black liberation, had condemned the ruler as a "great coward" for fleeing Mussolini's troops in I935, yet went on to dub him the "black Christ" of his Back to Africa movement. During the 50 an and 6os some 2,500 West Indians and African Americans who were inspired by Garvey, and believed Ethiopia to be the one true "Zion", went to live in the vicinity of Addis Ababa, in what is now Shashamane village. Only 300 of their number are believed to remain today. 
During his public presentation at the Limerick bookstore on IIth October Dr. Johannis Leeuwenburg of the Royal Tropical Institute of Amsterdam highlighted the numerous rewards Dr. Asfa-Wossen Asserate has received as a historian scholar, but also praised him for his balanced rehabilitation of the emperor (Dr. Asfa-Wossen Asserate is himself a distant relation of Selassie). Dr. Eddy Boutmans who interviewed him recalled the visits of the Emperor to Antwerp and Ghent as well as the role which the Force Publique Belgo-Congolaise played in freeing Ethiopia from the Italian occupation (the battle of Gambela).

Dr. Asserate recalled the rather funny anecdote that when Haile Selassie was crowned as Emperor it started to rain in Jamaica - after two years of drought - as predicted by Marcus Garvey. Dr. Asserate nevertheless suggested the Rastafarians should ask the Ethiopian Orthodox church to have Haile Selassie canonized as a kind of saint as was done for the last Russian Tsar and his family (on 15 August 2000 Tsar Nicholas II and his family were canonized as passion bearers, a title commemorating believers who face death in a Christlike manner, by the Russian Orthodox Church). Not without humor Dr. Asserate referred also to the some I5,000 white German Rastafarian claiming to be Africans.

The Ethiopian royal family promoted myths of its own, particularly its vaunted descent from King Solomon, the legendary third king of Israel. Selassie proclaimed himself a collateral descendant of Solomon's wife, the Queen of Sheba (who may or may not have come from present day Yemen). Yet for all the dizzying Semitic connections, Asserate reminds us, Ethiopia converted to Christianity in the fourth century AD, when the Ark of the Covenant was allegedly transferred there from southern Egypt. The Old Testament casket, lined with gold to accommodate the two tablets of the Ten Commandments, is said to reside today in the church of St Mary of Zion, near the Eritrean border (Axum, Tigray).

Dr. Asserate remains sober enough to understand that the evidence for Ethiopia's Semitic past is far from watertight: all people need myths. The Germans have their Niebelungen, the British have their King Arthur and when no clear trace can be established a link with the Knight Templars is often quickly assumed.

But it remains an historical anachronism that while claiming a long genealogical record of the House of David with a line of 3000 years, the Falasha were in due course forgotten. The immigration of Ethiopian Jews to the Land of Israel took place in two waves of mass immigration assisted by the Israeli government: Operation Moses (1984) and Operation Solomon (1991). Today Israel is home to the largest Beta Israel community ("House of Israel" or "Community of Israel" also known as Ethiopian Jews) in the world with about I25,500 citizens of Ethiopian descent who are mainly assembled in the smaller urban areas of central Israel. Dr. Asserate estimated that around 1o,0oo Falasha now remain in in Ethiopia.

He concluded his well attended lecture with the words: "If you want to remain friends with Ethiopians don't tell them Emperor Haile Selassie was a God". 